\title{
Pemanfaatan Mobile Phone App dalam Pencegahan dan Penanggulangan HIV pada Remaja: A Community-Based HIV Prevention Program
}

\author{
Irma Darmawati $^{*}$, Linlin Lindayani² iD \\ ${ }^{I}$ Prodi Keperawatan, Universitas Pendidikan Indonesia, Bandung, Indonesia \\ ${ }^{2}$ Sekolah Tinggi Ilmu Keperawatan PPNI Jawa Barat, Bandung, Indonesia \\ *Corresponding author: irma77@gmail.com
}

\begin{abstract}
Pemahaman HIV/AIDS merupakan masalah kesehatan global. Jumlah pengidap Orang Dengan AIDS (ODHA) di Kota Tangerang Selatan mencapai 598 pasien dan trend nya semakin meningkat setiap tahun. Pelaksanaan kegiatan pengabdian masyarakat ini memberikan solusi melalui pemanfaatan mobile app dalam pencegahan HIV kepada masyarakat sehingga masyarakat memiliki soft skill dan hard skill yang tepat untuk memproteksi diri mereka terhadap bahaya dari penularan HIV. Metode kegiatan dilakukan melalui pemberdayaan masyarakat dengan rangkaian kegiatan penyuluhan, pelatihan, pendidikan, dan pembinaan, serta penerapan aplikasi di mobile phone untuk sebagai upaya promosi dan preventif terhadap HIV. Hasil pelaksanaan kegiatan mampu meningkatkan kemampuan soft skill dan hard skill masyarakat terhadap penularan HIV, terbentuknya metode dan sistem pencegahan HIV yang berbasis komunitas, serta pemanfaatan mobile-phone app yang sederhana murah dan efektif yang bisa digunakan untuk pendidikan kesehatan dan monitoring perilaku beresiko terhadap penularan HIV.
\end{abstract}

Keywords: HIV/AIDS, Mobile Phone App, Remaja

\section{Abstract}

HIV/AIDS is a global health problem. The number of people living with AIDS (PLWHA) in South Tangerang City reached 598 patients and the trend is increasing every year. The implementation of this community service activity provides solutions through the use of mobile apps in HIV prevention to the community so that people have the right soft skills and hard skills to protect themselves against the dangers of HIV transmission. The method of activity is carried out through community empowerment with a series of outreach, training, education and coaching activities, as well as the application of applications on mobile phones for promotion and prevention of HIV. The results of the activity were able to improve the soft skills and hard skills of the community against HIV transmission, the formation of community-based HIV prevention methods and systems, and the use of a simple, cheap and effective mobile-phone app that can be used for health education and monitoring of risk behaviors against HIV transmission.

Keywords: HIV/AIDS, Mobile Phone App, Adolescence

\section{Introduction}

Human Immunodeficiency Virus atau HIV adalah virus yang menyerang sel darah putih di dalam tubuh (limfosit) yang mengakibatkan turunnya kekebalan tubuh manusia (Gunawan et al., 2016; Sejati \& Wijaya, 2017). Orang yang dalam darahnya terdapat virus HIV dapat tampak sehat dan belum tentu membutuhkan pengobatan, orang tersebut dapat menularkan virusnya kepada orang lain (Gunawan et al., 2016; Marlinda \& Azinar, 2017). Acquired Immune Deficiency Syndrome atau AIDS adalah sekumpulan gejala penyakit yang

$\begin{array}{lll}\text { History: } & & \text { Publisher: Undiksha Press } \\ \text { Received } & \text { : 2 Juni } 2020 & \text { Licensed: This work is licensed under } \\ \text { Revised } & \text { : 1 Juli } 2020 & \text { a Creative Commons Attribution 3.0 License } \\ \text { Accepted } & \text { : 23 Juli } 2020 & \text { : }\end{array}$


timbul karena kekebalan tubuh yang menurun yang disebabkan oleh infeksi HIV (Nuzzillah \& Sukendra, 2017; Sumartini \& Maretha, 2020). Akibat menurunnya kekebalan tubuh pada seseorang maka orang tersebut sangat mudah terkena penyakit seperti TBC, candidiasis, berbagai radang pada kulit, paru, saluran pencernaan, otak dan kanker. (KPAD Kab. Jember, 2015) (Gunawan et al., 2016). Jadi, jika seseorang dinyatakan positif HIV/AIDS maka akan terjadi penurunan kesehatan fisik maupun psikologis (Mursidi et al., 2018).

Laju infeksi HIV baru di Indonesia mengalami peningkatan yang drastis dibandingkan dengan negara-negara lain di Asia yang mengalami penurunan, rata-rata sebesar 3,2\% kasus HIV baru terdeteksi setiap tahun nya di Indonesia \% (Aryani \& Pramitasari, 2018; Diah Fatmala, 2016; Sejati \& Wijaya, 2017; UNAIDS, 2016). Jawa Barat merupakan salah satu provinsi yang mengalami moderenisasi di Indonesia yang jumlah penderita HIV/AIDS nya terbesar ke empat setelah Jakarta, Jawa Timur, dan Papua 18.727. Jawa Barat menempati kota tertinggi dengan prevalensi HIV sebanyak 3.912 jiwa. Selanjutnya, sejumlah 5.714 anak kelompok usia 15-19 tahun terinfeksi HIV dan 2.208 diantaranya terdiagnosa AIDS. Sedangkan, jumlah pengidap Orang Dengan HIV/AIDS (ODHA) di Kota Tangerang Selatan mencapai 598 pasien. Dari jumlah itu, tercatat 17 penderita di antaranya telah meninggal dunia. Data tersebut diperoleh dari Komisi Penanggulangan Aids (KPA) Provinsi Banten yang menyebutkan, jika penyebaran virus Human Immunodeficiency Virus (HIV) cukup tinggi di wilayah Kabupaten Tangerang, Kota Tangerang dan Kota Tangerang Selatan. Kota ini memiliki karakteristik tersendiri dibanding kawasan pemukiman penduduk daerah lainnya. Di kawasan ini, banyak dihuni oleh para pegawai, pelajar, mahasiswa, dan wisatawan. Kehadiran pegawai industri tentunya tidak hanya mendatangkan dampak positif, namun ada juga dampak negatifnya. Hal tersebut berdampak terhadap perubahan perilaku yang beresiko terhadap penularan penyakit HIV seperti seks bebas, penggunaan zat-zat adiktif terlarang, perilaku menyimpang lainnya. Hal, ini didukung oleh data yang diberikan oleh Kementerian Kesehatan RI.

Kementrian Kesehatan RI (2015) menyatakan bahwa prevalensi kasus baru AIDS ditemukan pada kelompok usia 20-29 tahun yakni sebesar 31,8\%, dengan masa inkubasi 10 tahun maka awal terkena HIV berkisar pada usia 10-29 tahun yang termasuk dalam kelompok usia remaja. Prevalensi kasus baru AIDS pada kelompok remaja sendiri ditemukan sebesar 2,9\% yang bermakna bahwa masa awal terinfeksi HIV pada kisaran usia sekolah 6-12 tahun. Pada masa ini anak sudah mulai mencoba coba untuk aktif secara seksual dan tinggi rasa ingin tahunya terhadap penyalahgunaan narkotika sehingga menjadi kelompok usia yang sangat rentan terhadap penularan HIV (Aviyah \& Farid, 2014). Penularan HIV dilaporkan paling banyak melalui seks bebas baik pada remaja atapun yang sudah berkeluarga dan melalui penggunaan narkoba suntik secara bergantian. Apabila pencegahan tidak dilakukan secara agresif dan komprehensif dengan pendekatan berbasis masyarakat, maka dikhawatirkan HIV akan sulit untuk dikendalikan (Kana et al., 2016). Hal tersebut akan berdampak besar terhadap perkembangan suatu bangsa, bisa menjadi penyebab loss generation dan berkurangnya produktifias secara ekonomi maupun sosial.

Penggunaan mobile app dalam upaya pencegahan HIV/AIDS pada remaja ini menjadi salah satu alternatif yang inovatif yang dapat diterapkan pada kader (Manurung et al., 2020). Mengaplikasikan pendekatan mobile app dalam upaya pencegahan HIV pada remaja juga dikaji lebih lanjut oleh (L'Engle, Mangone, Parcesepe, Agarwal, \& Ippoliti, 2016) dalam kajian sistematik review terhadap 35 artikel hasil aplikasi program pencegahan HIV berbasis mobile phone pada 7 negara. Promosi kesehatan berbasis mobile phone merupakan pendekatan yang mudah diterima pada semua kalangan saat ini terutama pada remaja dengan konten yang simpel, sederhana namun informatif.

Penelitian yang dilakukan oleh (Hananto, 2017) pada pasien dengan diabetes melitus. Menunjukkan bahwa pendekatan ini dinilai efektif dan efisien dalam meningkatkan self- 
management serta pencegahan komplikasi akibat diabetes. Penerapan mobile app pada remaja dengan risiko HIV ini diterapkan oleh (Chiou, Liao, Liu, \& Hsu, 2020) dalam bentuk SBS App yang meliputi 5 fitur diantaranya: record, output, dan resource connection; information provision; testing services ; interaction ; dan online statistic. Responden remaja diamati selama 6 bulan penelitian dan didapatkan hasil adanya peningkatan signifikan dalam pengetahuan, perilaku, motivasi dan keterampilan pencegahan hiv, serta adanya penurunan perilaku anal intercourse dan penggunaan obat pada remaja. Penggunaan mobile phone app sangat diperlukan untuk meningkatkan kesadaran atas perilaku beresiko seperti seks bebas dan penggunaan obat pada remaja. Pendekatan Pencegahan HIV pada remaja dapat dilakukan dengan pendekatan pembentukan kader yang peduli terhadap remaja dan juga memiliki motivasi dalam upaya pencegahan HIV/Aids pada remaja (Janah et al., 2019). Beberapa penelitian yang dilakukan tentang penggunaan mobile app dalam bidang Kesehatan.

Mempertimbangkan wilayah dengan resiko tinggi penularan HIV di wilayah tangerang selatan, maka kami mengembangkan upaya pencegahan HIV melalui pendekatan penerapan mobile phone app agar masyarakat khususnya remaja memiliki soft skill dan hard skill yang tepat untuk memproteksi diri mereka terhadap bahaya dari penularan HIV. upaya pencegahan melalui mobile aplication ini dibentuk sebagai upaya community-based HIV prevention yang mana selama ini konseling hanya dilaksanakan di level rumah sakit besar dengan tingkat aksesibilitasnya yang susah. Dengan community-based HIV prevention ini, ini akan mendekatkan masyarakat dalam upaya pencarian informasi yang tepat mengingat banyak kesalah fahaman tentang HIV yang beredar melalui media.

Program pengabdian masyarakat ini akan memberikan kontribusi besar kepada masyarakat dan pemerintah terutama dalam pencegahan HIV/AIDS yang sulit dikendalikan. Selama ini, upaya pencegahan melalui hubungan seksual berbasis pada slogan setia pada satu pasangan dan penggunaan kondom. Dimana penggunaan kondom itu sangat kontroversial dan tidak diterima oleh masyarakat, sehingga tidak heran HIV di Indonesia sulit dikendalikan. Dengan adanya program ini, kami akan memberikan kemampuan kepada masyarakat yang bukan hanya sebatas pendidikan kesehatan, tetapi juga pembentukan sistem dan metode, serta pembinaan yang berkesinambungan. Sehingga program ini akan menjadi solusi praktis yang berbasis masyarakat dalam upaya peningkatan kapasitas masyarakat terhadap pencegahan dan penanggulangan HIV di Indonesia.

\section{Materials and Methods}

Jenis pelaksanaan program pengabdian masyarakat ini adalah kombinasi pemberdayaan masyarakat dengan rangkaian kegiatan penyuluhan, pelatihan, pendidikan, dan pembinaan, serta penerapan aplikasi di mobile phone untuk sebagai upaya promosi dan preventif terhadap HIV. Kegiatan dilakukan dalam 2 kerangka program yakni Development program dan mantain sustainable program.

Development program dilakukan beberapa Langkah kegiatan yaitu 1) Focus Group Discussion: Analisa permasalahan dan kebutuhan untuk modifikasi program. 2) Pembentukan kader HIV. 3) Penerapan mobile App dalam penyebaran informasi seputar HIV dan reminder system dan 4) Pemberdayaan masyarakat. Sedangkan program mantain sustainable program lebih rinci pada Tabel 1. Seluruh rangkaian kegiatan dilaksanakan di puskesmas Bakti Jaya Tangerang Selatan pada sejumlah 16 perwakilan kader dari 5 kelurahan di wilayah Bakti Jaya. 
Tabel 1. Masalah, Solusi, Luaran Program

\begin{tabular}{|c|c|c|}
\hline Masalah & Solusi/Program & Luaran \\
\hline $\begin{array}{l}\text { Resiko tinggi } \\
\text { penularan HIV } \\
\text { dikawasan } \\
\text { Tangerang }\end{array}$ & $\begin{array}{l}\text { 1) Bekerjasama dengan puskesmas dan } \\
\text { pemerintah setempat } \\
\text { melaksanakan kegiatan pendidikan } \\
\text { kesehatan HIV/AIDS }\end{array}$ & $\begin{array}{l}\text { 1. Terbentuknya } \\
\text { metode dan sistem } \\
\text { pencegahan HIV } \\
\text { yang berbasis }\end{array}$ \\
\hline Selatan & $\begin{array}{l}\text { 2) Menerapkan teknologi informasi yang } \\
\text { berupa mobile phone app yang berisi } \\
\text { informasi pencegahan HIV dan } \\
\text { penanggulangannya yang lebih } \\
\text { interaktif. Aplikasi ini berguna bukan } \\
\text { hanya untuk pendidikan kesehatan saja } \\
\text { tetapi juga sebagai reminder system. } \\
\text { 3) Pembentukan kader HIV sebagai garda } \\
\text { terdepan dalam pencegahan HIV }\end{array}$ & komunitas \\
\hline $\begin{array}{l}\text { Kader belum } \\
\text { dilakukan } \\
\text { pembinaan }\end{array}$ & $\begin{array}{l}\text { 1) Pemberdayaan masyarakat melalui } \\
\text { penyuluhan, pelatihan, pendidikan, dan } \\
\text { pembinaan kesehatan terutama } \\
\text { berkaitan dengan pencegahan HIV. } \\
\text { Adapun konten pencegahan HIV } \\
\text { berfokus pada peningkatan kapasitas } \\
\text { masyarakat dalam hal pengetahuan, } \\
\text { sikap, dan perilaku terhadap penularan } \\
\text { HIV. Selain itu, program ini juga akan } \\
\text { berfokus pada penurunan perilaku } \\
\text { beresiko terhadap penularan HIV. } \\
\text { 2) Sustainable program: untuk menjaga } \\
\text { keberlanjutan program kedepannya } \\
\text { akan dilakukan kerjsama secara } \\
\text { intensif dengan pihak puskesmas } \\
\text { setempat. }\end{array}$ & $\begin{array}{l}\text { 1. Peningkatan soft } \\
\text { skill dan hard skill } \\
\text { masyarakat } \\
\text { terhadap penularan } \\
\text { HIV Pemanfaatan } \\
\text { 2. apd and } \\
\text { mobile-phone app } \\
\text { yang sederhana } \\
\text { murah dan efektif } \\
\text { yang bisa } \\
\text { digunakan untuk } \\
\text { pendidikan } \\
\text { kesehatan dan } \\
\text { monitoring perilaku } \\
\text { beresiko terhadap } \\
\text { penularan HIV }\end{array}$ \\
\hline
\end{tabular}

\section{Results and Discussion}

Pelaksanaan kegiatan dilaksanakan di Aula Lt. 2 puskesmas Bakti Jaya Tangerang Selatan. Program terbagi dalam developmental program dan maintain sustainable program. Kegiatan developmental program diawali dengan koordinasi, analisa permasalahan dan kebutuhan untuk modifikasi program dengan puskesmas, perencanaan pelaksanaan kegiatan pendidikan kesehatan HIV/AIDS, serta pembentukan kader HIV sebagai garda terdepan dalam pencegahan HIV dari kelompok masyarakat peduli Aids di wilayah puskesmas Bakti Jaya.

Kegiatan dilanjutkan dengan kegiatan inti pemaparan mengenai karakteristik dan perjalanan penyakit HIV pada masyarakat, khususnya kelompok remaja pada seluruh Kader HIV yang telah terbentuk. Kegiatan diawali dengan brainstorming fenomena HIV/AIDS di setiap wilayah tempat tinggal kader serta pengalaman kader dalam pendampingan pengobatan ODHA ke puskesmas. Sebagian kader menceritakan berbagai fenomena yang ada di kalangan warga mengenai kondisi HIV/AIDS di masyarakat. Beberapa kader sudah memiliki pengalaman mendampingi pasien HIV untuk pemeriksaan VCT dan juga pengobatan rutin ke puskemsas. Fenomena yang masih sulit dihadapi oleh masyarakat adalah 
adanya stigma pada penderita HIV yang ada di wilayah bakti jaya sehingga mengakibatkan perasaan malu dan tidak datang kembali untuk berobat, yang mengakibatkan kondisi pasien semakin menurun dan tidak jarang beberapa diantaranya meninggal. Kegiatan dilanjutkan penjelasan materi mengenai HIV dan karakteristiknya, Fakta dan mitos seputar HIV, upaya pencegahan dan pengobatan HIV/AIDS di kalangan remaja, serta peran kader HIV di masyarakat. Kegiatan pelatihan kader terkait HIV/AIDS dapat dilihat pada Gambar 1.

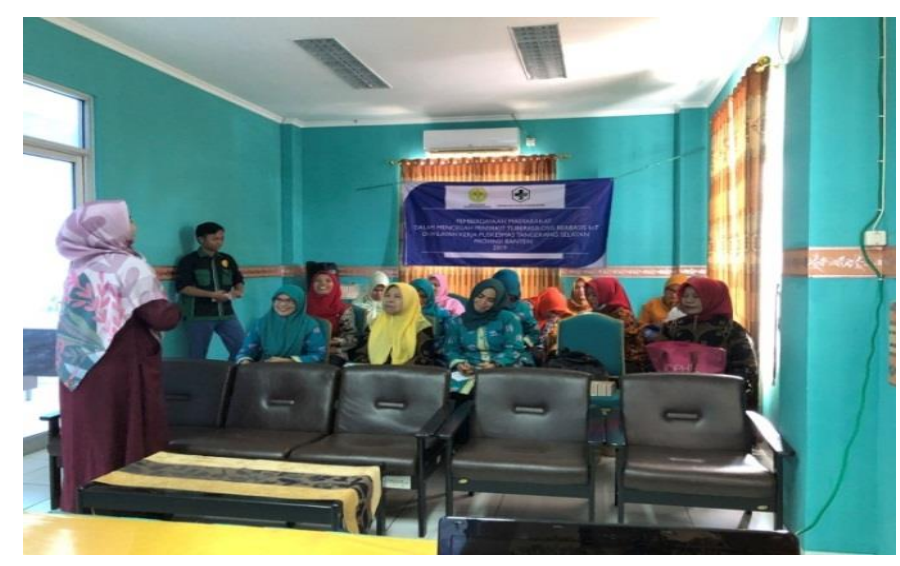

Gambar 1. Pelatihan kader terkait HIV/AIDS

Pada agenda selanjutnya dilakukan kegiatan simulasi penerapan mobile App dalam penyebaran informasi seputar HIV dan reminder systems. Kegiatan simulasi dipraktekan langsung oleh setiap kader melalui handphone masing-masing didampingi oleh fasilitator. Kegiatan pendampingan penerapan mobile phone App HIV/AIDS dapat dilihat pada Gambar 2 .

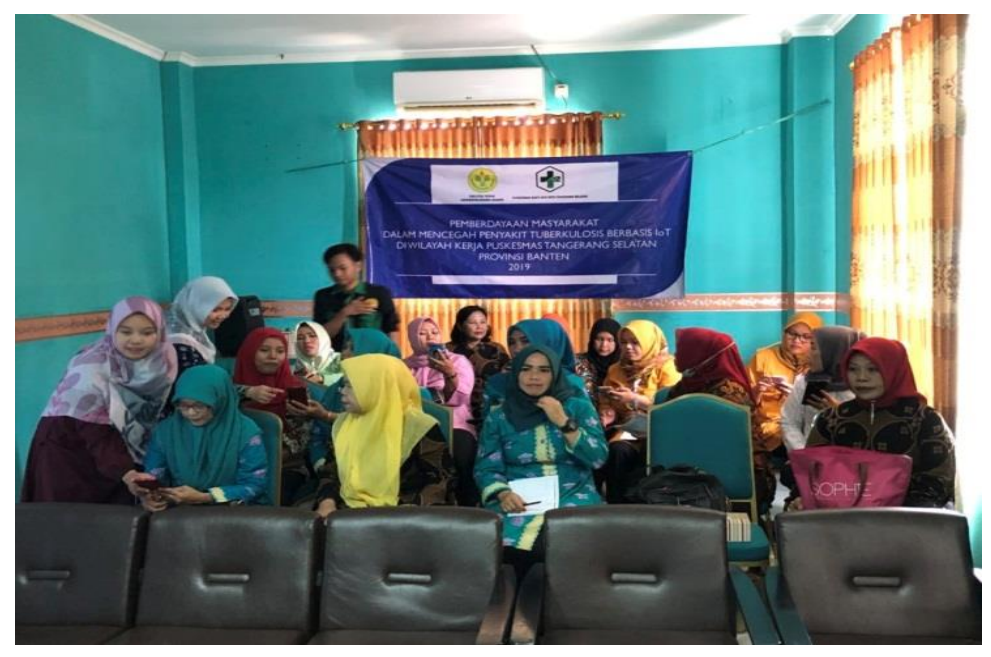

Gambar 2. Pendampingan penerapan mobile phone App HIV/AIDS

Kegiatan dilakukan dengan konsep pemberdayaan masyarakat yang dalam hal ini diwakili oleh kader sebagai warga peduli Aids di tempat tinggal masing masing. Antusiasme kader dalam mengikuti kegiatan dinilai baik dan siap menjadi perpanjangan tangan dari puskesmas dalam pelaksanaan program pencegahan HIV/Aids di masyarakat. Kader HIV di wilayah Puskesmas Bakti Jaya Tangerang Selatan dapat dilihat pada Gambar 3. 


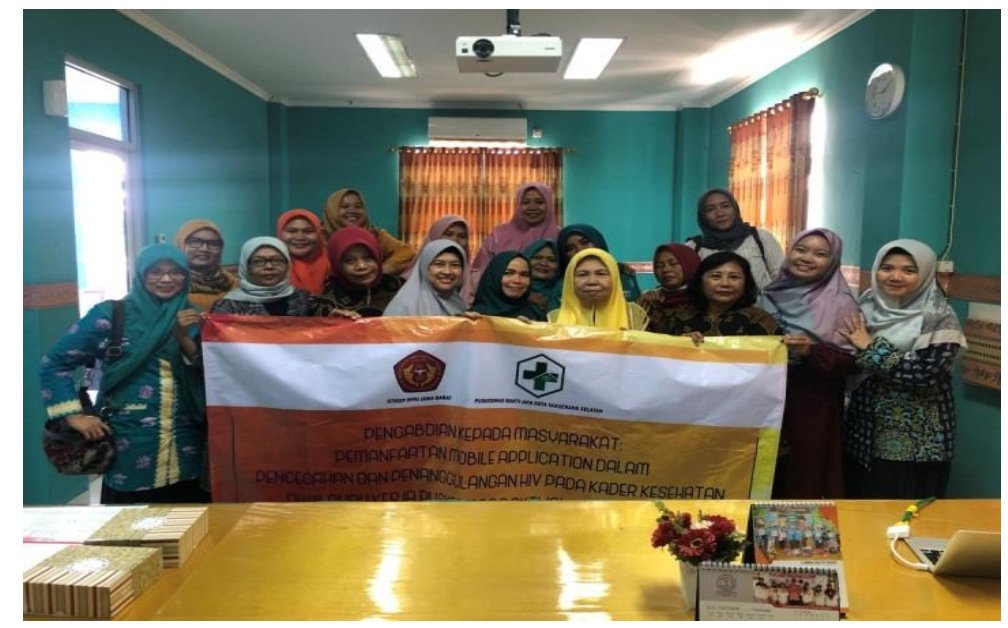

Gambar 3. Kader HIV di wilayah Puskesmas Bakti Jaya Tangerang Selatan

Kegiatan penyuluhan dan pemberdayaan kader ini dilanjutkan dengan koordinasi dengan pihak puskesmas untuk menjaga keberlanjutan program kedepannya akan dilakukan kerjsama secara intensif. Kader akan dilibatkan dalam integrasi program pengabdian ini dengan kegiatan rutin puskesmas, salah satunya dalam penemuan kasus baru, pendampingan pasien pemeriksaan VCT dan pengobatan di Puskesmas. Dokumentasi video kegiatan dapat diakses melalui link Youtube : https://www.youtube.com/watch?v=Tnq9laLktjQ

Kegiatan Pemberdayaan masyarakat dalam upaya pencegahan HIV/AIDS pada remaja ini mengevaluasi pengetahuan dan keterampilan kader selama sebelum dan sesudah kegiatan dilaksanakan. Berdasarkan hasil tersebut dapat dilihat adanya peningkatan pengetahuan dan keterampilan kader dalam upaya pencegahan HIV pada remaja yang ditunjukkan pada Tabel 2 berikut.

Tabel 2. Pengetahuan dan keterampilan kader sebelum dan sesudah program dilaksanakan

\begin{tabular}{lccc}
\hline & Sebelum Mean (SD) & Setelah Mean (SD) & P value \\
\hline Pengetahuan & $65,5(2,45)$ & $74,5(2,15)$ & 0,001 \\
Keterampilan & $66,5(2,17)$ & $72,5(2,62)$ & 0,001 \\
\hline
\end{tabular}

Berdasarkan table 2 terjadi peningkatan pengetahuan dan keterampilan kader dalam upaya pencegahan HIV pada remaja. Hal ini ditunjukkan pada peningkatan nilai rata-rata sebelum dan sesudah adanya kegiatan dimana, pengetahuan sebelum kegiatan menunjukkan rata-rata 65,5 dan setelah kegiatan meningkat 74,5. Sedangkan keterampilan 66,5 sebelum kegiatan menjadi 72,5 setelah adanya kegiatan.

Berdasarkan hasil tersebut dapat dikatan bahwa dengan adanya kegiatan pengabdian masyarakat ini yang dilaksanakan dua program yaitu program Development program dan mantain sustainable program berdampak positif terhadap pengetahuan dan keterampilan Kader dalam upaya pencegahan HIV/AIDS pada remaja. Faktor- faktor yang mempengaruhi seseorang untuk berperilaku yang benar terhadap penanggulangan HIV dan AIDS adalah pengetahuan, sikap dan dukungan sosial (Yuliza et al., 2019). Kader dalam hal ini memegang peran yang sangat tinggi dari sisi dukungan sosial yang bisa diberikan pada remaja. Kader kesehatan dalam hal ini sebagai Warga Peduli Aids memiliki kepedulian untuk menciptakan lingkungan tempat tinggalnya nyaman dan bebas dari ancaman HIV/Aids. Dukungan yang dapat diberikan kader juga dapat melalui dukungan informasi berupa sosialisasi, dukungan instrumental melalui pendampingan layanan tes HIV 
di puskesmas. Serta bisa pula diwujudkan dengan pendampingan ODHA untuk meningkatkan kualitas hidupnya (Manurung et al., 2020)

Dengan adanya kader-kader yang nantinya akan kembali kemasyrakatan akan memberikan pemahaman atau pendidikan pada orang-orang yang ada di sekitarnya khususnya remaja. Kader-kader ini selain dibekali dengan pengetahuan tentang pencegahan HIP/AIDS juga dibekali dengan keterampilan penggunaan mobile app, yang akan lebih mudah menghadapi arak remaja yang pada saat ini ada pada arus teknologi yang sangat tinggi.

Mobile phone based intervention merupakan pendekatan yang sangat penting untuk meningkatkan pelayanan kesehatan yang berpusat pada pasien, identifikasi penyakit secara dini, dan upaya pencegahan terhadap penyakit-penyakit yang bisa dilakukan pengelolaan perilaku risiko nya seperti pada kasus HIV/AIDS (L'Engle et al., 2016). Beberapa penelitian terkait penggunaan teknologi sebagai upaya pencegahan penyakit sudah mulai banyak dilakukan. Kemajuan teknologi saat ini tidak bisa dipisahkan dari kehidupan masyarakat. Berbagai informasi yang terjadi di berbagai belahan dunia kini telah dapat langsung diketahui berkat kemajuan teknologi (globalisasi) (Janah et al., 2019).

Beberapa program upaya pencegahan sudah ada di masyarakat seperti Warga peduli Aids yang harus semakin digalakan dan menggunakan media media mobile aplikasi untuk menunjang pelaksanaan program program tersebut. Berdasarkan hasil evaluasi kader termotivasi untuk melaksanakan peran sebagai kader HIV di masyarakat, penggunaan mobile-phone app yang sederhana murah dan efektif ini mudah digunakan untuk pendidikan kesehatan dan monitoring perilaku beresiko terhadap penularan HIV di masyarakat.

\section{Conclusion}

Siswa Program penerapan mobile phone app dalam upaya pencegahan dan penanggulangan HIV pada remaja ini terlaksana dengan baik dan efektif dalam meningkatkan soft skill dan hard skill pada kader HIV di Puskesmas Bakti Jaya Tangerang Selatan. Kegiatan pemanfaatan mobile phone app efektif dan bermakna dalam meningkatkan pengetahuan serta keterampilan kader sebagai upaya pencegahan HIV/Aids pada remaja di masyarakat. Diperlukan optimalisasi keberlanjutan program berkoordinasi dengan puskesmas dalam hal penemuan kasus dan pendampingan pasien di masyarakat.

\section{References}

Aryani, L., \& Pramitasari, R. (2018). Perkembangan Kasus Hiv Di Kota Semarang : Tinjauan Karakteristik Dan Aspek Lingkungan the Development of Hiv Cases in Semarang: Review of Characteristics and Environmental Aspects. J. Kesehat. Masy. Indones, 13(1), 2018. https://jurnal.unimus.ac.id/index.php/jkmi/article/download/3438/3260

Aviyah, E., \& Farid, M. (2014). Religiusitas, kontrol diri dan kenakalan remaja. Persona: Jurnal Psikologi Indonesia, 3(02). https://doi.org/10.30996/persona.v3i02.376

Chiou, P. Y., Liao, P. H., Liu, C. Y., \& Hsu, Y. T. (2020). Effects of mobile health on HIV risk reduction for men who have sex with men. AIDS Care - Psychological and SocioMedical Aspects of AIDS/HIV, 32(3), 316-324. https://doi.org/10.1080/09540121.2019.1668531

Diah Fatmala, R. (2016). Faktor Predisposing, Enabling Dan Reinforcing dalam Pemanfaatan VCT oleh Laki-Laki Seks dengan Laki-Laki (1Sl). Berkala Epidemiologi, 4(1), 138150. https://doi.org/10.20473/jbe.v4i1.138-150

Gunawan, Y. T., Prasetyowati, I., \& Ririanty, M. (2016). Hubungan Karakteristik ODHA Dengan Kejadian Loss To Follow Up Terapi ARV Di Kabupaten Jember. Jurnal 
IKESMA, 12(1),

$53-64$. https://jurnal.unej.ac.id/index.php/IKESMA/article/download/4822/3554/

Hananto, K. S. (2017). Program Self Management berbasis mobile phone pada pasien Diabetes Melitus Tipe 2. 2(2), 68-73.

Izah, N., Zulfiana, E., \& Qudriani, M. (2019). Pembentukan kader KRR pada siswa SMK. EDimas: Jurnal Pengabdian Kepada Masyarakat, 10(1), 111-115. https://doi.org/10.26877/e-dimas.v10i1.3558

Janah, E. N., Zakiudin, A., \& Lestari, A. M. (2019). Pencegahan HIV/Aids Melalui Penyuluhan Kesehatan Reproduksi Dan Pembentukan Kader Kesehatan Remaja. PROSIDING SEMINAR NASIONAL LPPM UMP, 54-60.

Kana, I. M. ., Nayoan, C. R., \& Limbu, R. (2016). Gambaran Perilaku Pencegahan Hiv Dan Aids Pada Lelaki Suka Lelaki (Lsl) Di Kota Kupang Tahun 2014. Unnes Journal of Public Health, 5(3), 252. https://doi.org/10.15294/ujph.v5i3.10995

Kemenkes. (2015). Profil Kesehatan Indonesia 2015. Jakarta: Kementerian Kesehatan Republik Indonesia.

L'Engle, K. L., Mangone, E. R., Parcesepe, A. M., Agarwal, S., \& Ippoliti, N. B. (2016). Mobile phone interventions for adolescent sexual and reproductive health: A systematic review. Pediatrics, 138(3). https://doi.org/10.1542/peds.2016-0884

Manurung, I. F. E., Maulesu, R., Weraman, P., \& Roga, A. U. (2020). Sikap, Keyakinan, Niat Dan Perilaku Masyarakat Binaan Kader Warga Peduli Aids (Wpa) Terhadap Penanggulangan Hiv Dan Aids Di Kota Kupang. IAKMI Jurnal Kesehatan Masyarakat Indonesia, 1(1), 25-34.

Marlinda, Y., \& Azinar, M. (2017). Perilaku Pencegahan Penularan Hiv/Aids. JHE (Journal of Health Education), 2(2), 185-193. https://doi.org/10.15294/jhe.v2i2.22620

Mursidi, A., Noviandari, H., \& Soetopo, D. (2018). Pelatihan Penangulangan dan Pencegahan HIV / AIDS. KHAZANAH PENDIDIKAN, XII(1), 83-94.

Nuzzillah, N. A., \& Sukendra, D. M. (2017). Analisis Pengetahuan Dan Sikap Narapidana Kasus Narkoba Terhadap Perilaku Berisiko Penularan Hiv/Aids. JHE (Journal of Health Education), 2(1), 11-19. https://doi.org/10.15294/jhe.v2i1.18816

Sejati, A., \& Wijaya, I. P. (2017). Kardiomiopati pada Penderita Infeksi HIV. Jurnal Penyakit Dalam Indonesia, 1(2), 132. https://doi.org/10.7454/jpdi.v1i2.47

Sumartini, S., \& Maretha, V. (2020). Efektifitas Peer Education Method dalam Pencegahan HIV/AIDS terhadap Pengetahuan Dan Sikap Remaja. Jurnal Pendidikan Keperawatan Indonesia, 6(1), 77-84. https://doi.org/10.17509/jpki.v6i1.21130

UNAIDS, G. A. (2016). Global AIDS update 2016. Geneva, Switzerland: World Health Organization Library.

Yuliza, W. T., Hardisman, H., \& Nursal, D. G. A. (2019). Analisis Faktor yang Berhubungan dengan Perilaku Pencegahan HIV/AIDS Pada Wanita Pekerja Seksual di Kota Padang. Jurnal Kesehatan Andalas, 8(2), 376-384. https://doi.org/10.25077/jka.v8i2.1015 